\title{
Implementasi Aplikasi Wifi TB Berdasarkan Persepsi Kemudahan dan Kemanfaatan di Kota Semarang
}

\author{
Arif Kurniadi ${ }^{1}$, Evina Widianawati ${ }^{2}$, Edi Jaya Kusuma ${ }^{3}$, Marko Ferdian Salim ${ }^{4}$ \\ 1,2,3Program Diploma III Rekam Medis, Fakultas Kesehatan Masyarakat, Universitas Dian \\ Nuswantoro \\ 4Program Sarjana Terapan Manajemen Informasi Kesehatan, Sekolah Vokasi, Universitas Gadjah \\ Mada \\ arif.kurniadi@dsn.dinus.ac.id ${ }^{1}$, markoferdiansalim@mail.ugm.ac.id ${ }^{4}$
}

\section{ABSTRAK}

Diajukan 31 Juli 2019 Diperbaiki 4 Mei 2020 Diterima 6 Mei 2020

Latar Belakang: Tuberkulosis (TB) merupakan salah satu dari sepuluh penyakit penyebab kematian di dunia. Kasus TB yang ditemukan harus dicatat dan dilaporkan oleh setiap fasilitas pelayanan kesehatan sesuai format yang ditentukan.

Tujuan: Mengetahui pengaruh persepsi kemanfaatan, kemudahan dan kendala terhadap implementasi penggunaan aplikasi Wifi TB.

Metode: Penelitian ini merupakan penelitian kuantitatif dengan desain observasional analitik. Penelitian dilaksanakan di wilayah kerja Dinas Kesehatan Kota Semarang dengan melibatkan dokter praktik mandiri dan dokter klinik pratama sebagai responden sebanyak 129 orang pada tahun 2019.

Hasil: Responden yang mengisi angket sebanyak 129 orang, 60\% belum menggunakan aplikasi dan $40 \%$ sudah menggunakan aplikasi. Berdasarkan hasil skor angket dengan skala $1-5$, diketahui skor persepsi kemanfaatan dan kemudahan adalah 4, skor kendala penggunaan adalah 2, skor implementasi penggunaan 3,8 serta skor efektivitas dan kepuasan adalah 4. Berdasarkan hasil uji statistik diperoleh nilai sig $F=0,000$ dan $R$-square $=70,1 \%$, artinya persepsi kemanfaatan, kemudahan dan kendala penggunaan aplikasi secara bersama-sama berpengaruh siginifikan terhadap implementasi penggunaan aplikasi Wifi TB sebesar 70,1\%.

Kesimpulan: Persepsi kemanfaatan, kemudahan dan kendala penggunaan mempengaruhi implementasi penggunaan aplikasi sebesar $70,1 \%$. Disarankan kepada pengembang program dan dinas terkait untuk selalu memberikan sosialisasi dan pelatihan kepada pengguna aplikasi Wifi TB.

Kata Kunci: aplikasi wifi TB; persepsi; kendala

\section{ABSTRACT}

Background: Tuberculosis (TB) is one of the ten leading causes of death in the world. TB cases found must be recorded and reported by each health service facility according to the format specified.

Objective: To determine the effect of perceived usefulness, ease and usage constraints on the implementation of the use of the Wifi TB application.

Methods: This research is quantitative research with an analytic observational design. The study was conducted in the working area of the Semarang City Health Office involving independent practising doctors and clinic doctors as many as 129 respondents in 2019.

Results: 129 respondents completed the questionnaire, 60\% had not used the application and 40\% had used the application. Based on the results of the questionnaire score with a scale of 1-5, it is known that the score of perceived usefulness and ease is 4, the score of usage constraints is 2, the score of implementation is 3.8 and the effectiveness and satisfaction score is 4 . Based on the statistical test results obtained sig $F=0,000$ and $R$ square $=70.1 \%$, meaning that the perceived usefulness, ease and usage constraints the application together have a significant effect on the implementation of the use of the Wifi TB application by $70.1 \%$.

Conclusion: Perceived usefulness, convenience and usage constraints affect the implementation of application usage by $70.1 \%$. It is recommended to program developers and related institution to always provide socialization and training to users of the Wifi TB application.

Keywords: wifi TB application; perception; constrain 
PENDAHULUAN

Tuberkulosis (TB) adalah suatu jenis penyakit infeksi menular yang disebabkan oleh agen biologi bakteri Mycobacterium Tuberculosis. Bakteri tersebut dapat berkembang di dalam organ tubuh dimana terdapat banyak oksigen serta aliran darah. Tuberculosis dapat menyerang berbagai organ, terutama paru-paru. Penularan dapat terjadi ketika pasien Tuberkulosis batuk atau bersin (Indah, 2018). Apabila seseorang penderita TB batuk, bersin, maupun berbicara dengan orang lain, maka bakteri akan ikut melalui percikan air liur dan terbang di udara (Kemenkes RI, 2011).

Menurut WHO (World Health Organization), Tuberkulosis (TB) merupakan salah satu dari 10 penyakit penyebab kematian (WHO, 2019). Profil Kesehatan di Indonesia tahun 2017 memperkirakan terdapat 992.441 kasus TB. Jumlah perkiraan kasus TB terbanyak di 5 wilayah di Indonesia yaitu Jawa Barat terdapat 156.149 kasus, Jawa Timur terdapat 119.490, Jawa Tengah terdapat 103.840 kasus, Sumatera Utara terdapat 73.488 kasus, dan Sumatera Selatan terdapat 40.311 kasus (Kemenkes RI, 2018) .

Dari data tersebut, Jawa Tengah merupakan wilayah ke-3 dengan jumlah kasus TB terbesar di Indonesia tahun 2017, yaitu berjumlah 28.842 kasus yang terbagi atas beberapa wilayah di Jawa Tengah. Menurut Badan Pusat Statistik Provinsi Jawa Tengah diperkirakan 5 Kabupaten/ Kota dengan jumlah kasus TB terbanyak di Jawa Tengah terdapat di Kota Semarang dengan 3882 kasus, Kab.Banyumas terdapat 3560 kasus, Kab.Cilacap terdapat 3006 kasus, Kab.Tegal terdapat 2556, dan Kota Tegal terdapat 1757 kasus (Kemenkes RI, 2018).

Strategi pengendalian kasus TB yaitu dengan strategi DOTS (Directly Observed Treatment Short-Course). DOTS memfokuskan pada penemuan dan penyembuhan pasien $\mathrm{TB}$, dengan memprioritaskan terhadap pasien TB menular. Departemen Kesehatan RI mulai menetapkan strategi nasional pengendalian kasus TB yaitu dengan strategi DOTS (Directly Observed Treatment Short-Course) yang diterapkan secara bertahap melalui puskesmas (BPS Jawa Tengah, 2017).

Program penanggulangan TB merupakan program pemerintah di bidang pencegahan dan pengendalian penyakit terhadap besarnya jumlah kasus TB di Indonesia. Kendala yang dihadapi saat ini adalah adanya kesenjangan yang terjadi karena perbedaan antara jumlah pasien kasus TB baru dan kasus TB diobati serta jumlah kasus TB yang dilaporkan. Diberlakukannya Wajib Notifikasi TB sesuai Peraturan Menteri Kesehatan No 67 Tahun 2016 tentang Penanggulangan Tuberkulosis, diharapkan pencatatan dan pelaporan kasus TB yang terintegrasi. Kasus TB yang ditemukan harus dicatat dan dilaporkan oleh setiap fasilitas pelayanan kesehatan sesuai format yang ditentukan.

Pemanfaatan aplikasi Wifi TB berbasis android merupakan salah satu pembaharuan terhadap sistem pencatatan dan pelaporan kasus TB. Smartphone mempunyai potensi yang baik untuk mendampingi pencatatan pasien atau komunitas di masyarakat (Kemenkes RI, 2015). Sasaran pengguna aplikasi Wifi TB adalah DPM (Dokter Praktik Mandiri) maupun klinik yang terkait dengan surveilans TB. Pengenalan aplikasi Wifi TB diawali dengan diselenggarakan workshop pada tanggal 23-24 Agustus 2018 oleh Dinas Kesehatan Provinsi Jawa Tengah bekerjasama dengan CTB (Challenge Tuberculosis) KNCV Provinsi Jawa Tengah kepada pengelola program TB Kabupaten/Kota se Jawa Tengah. Setelah penyelenggaraan workshop tersebut, Dinas Kesehatan Kab/Kota melakukan koordinasi dengan IDI (Ikatan Dokter Indonesia) terhadap penggunaan aplikasi Wifi TB. 
Penelitian ini dilakukan di wilayah kerja setiap Puskesmas di Kota Semarang yang sudah terpapar oleh sosialisasi penggunaan aplikasi Wifi TB kepada dokter praktik mandiri, klinik pratama yang berada di wilayah kerja Dinas Kesehatan Kota Semarang.

Tujuan penelitian ini yaitu sebagai berikut: (1) Untuk mengetahui pengaruh persepsi kemanfaatan, kemudahan dan kendala terhadap implementasi penggunaan aplikasi Wifi TB; (2) Untuk mengetahui persepsi kemanfaatan, kemudahan, kendala penggunaan dan kepuasan dari penggunaan aplikasi Wifi TB berbasis android.

\section{METODE}

Penelitian ini merupakan penelitian kuantitatif dengan desain observasional analitik. Analisis data menggunakan analisis kuantitatif secara deskriptif, dan analisis kuantitatif secara inferensial. Masing-masing pendekatan ini melibatkan pemakaian dua jenis statistik yang berbeda. pertama menggunakan statistik deskriptif dan yang kedua menggunakan uji regresi berganda.

Variabel penelitian sebagai berikut: persepsi kemanfaatan aplikasi, persepsi kemudahan aplikasi, kendala penggunaan aplikasi, implementasi penggunaan aplikasi, efektivitas penggunaan aplikasi, kepuasan penggunaan aplikasi.

Populasi yang digunakan dalam penelitian ini adalah dokter praktik mandiri dan dokter di klinik pratama di wilayah kerja 11 Puskesmas di Dinas Kesehatan Kota Semarang. Berikut daftar 10 Puskesmas: Puskesmas Karang Doro, Bandarharjo, Bulu Lor, Candi Lama, Kagok, Lamper Tengah, Poncol, Purwoyoso, Srondol, Tlogosari Wetan, Tlogosari Kulon. Jumlah responden yaitu 129 responden. Sampel yang digunakan adalah semua data dari total populasi.

Instrumen penelitian yang digunakan berupa angket penggunaan aplikasi Wifi TB dan dokumentasi. Teknik analisis data yang digunakan adalah

1. Uji Validitas dan Reliabilitas Butir Pertanyaan Angket

Dilakukan uji validitas dan realibilitas untuk mengetahui kevalidan dari setiap pertanyaan dan nilai keajegan (reliabel) dari pertanyaan. Dari hasil analisis diperoleh kesimpulan angket tersebut valid dan reliabel sehingga dapat digunakan untuk melakukan penelitian.

2. Analisis Deskriptif

Analisis deskriptif digunakan untuk menganalisis karakteristik responden, data hasil kuesioner di setiap variabel, setiap item pertanyaan di variabel penelitian. Analisis dilakukan dengan menggunakan rumus Mean, Modus dan Persentase.

3. Analisis Inferensial : Regresi Berganda Analisis regresi digunakan untuk menguji pengaruh variabel kemanfaatan, kemudahan dan kendala penggunaan terhadap implementasi penggunaan aplikasi Wifi TB.

\section{HASIL DAN PEMBAHASAN}

\section{A. Karakteristik Responden}

Hasil analisis deskriptif karakteristik responden dapat dilihat pada gambar 1 . Total Responden yang mengisi angket sebanyak 129 responden. 77 responden (60\% responden) belum menggunakan aplikasi Wifi TB, 52 responden (40\% responden) sudah menggunakan aplikasi. Dari 77 responden yang belum menggunakan aplikasi, 46 responden (60\% responden) berusia produktif yaitu usia 26-45 tahun dan 52 responden dengan lama bekerja $<10$ th. 64 responden (83\% responden) tidak mengikuti pelatihan aplikasi sedangkan dari 52 responden yang sudah menggunakan aplikasi, 36 responden ( $70 \%$ responden) berusia usia 36-55 tahun dan 28 responden dengan lama bekerja $>10$ th. Dilihat dari segi usia dan lama bekerja, responden yang menggunakan aplikasi termasuk responden berpengalaman kerja. 
Implementasi Aplikasi Wifi TB Berdasarkan Persepsi Kemudahan...

\begin{tabular}{|c|c|c|c|c|}
\hline \multicolumn{5}{|c|}{ Tabel 1. Karakteristik Responden } \\
\hline \multirow[b]{2}{*}{ No } & \multirow{2}{*}{\multicolumn{2}{|c|}{ Deskripsi }} & \multicolumn{2}{|c|}{ Jumlah Responden } \\
\hline & & & Belum & Sudah \\
\hline & \multirow{2}{*}{\multicolumn{2}{|c|}{ Total Responden }} & & \\
\hline 1 & & & 77 & 52 \\
\hline \multirow{2}{*}{2} & \multirow{2}{*}{ Sex } & Male & 29 & 13 \\
\hline & & Female & 48 & 39 \\
\hline \multirow{6}{*}{3} & \multirow{6}{*}{ Age } & 17-25th & 13 & 1 \\
\hline & & 26-35th & 20 & 9 \\
\hline & & 36-45th & 26 & 21 \\
\hline & & 46-55th & 14 & 15 \\
\hline & & 56-65th & 3 & 4 \\
\hline & & $>65$ th & 1 & 2 \\
\hline \multirow{3}{*}{4} & \multirow{3}{*}{$\begin{array}{l}\text { Jenis } \\
\text { Instansi }\end{array}$} & $\mathrm{DPM}$ & 18 & 15 \\
\hline & & DKP & 59 & 36 \\
\hline & & dll & & 1 \\
\hline \multirow{2}{*}{5} & \multirow{2}{*}{$\begin{array}{l}\text { Lama } \\
\text { Bekerja }\end{array}$} & $\leq 10$ th & 52 & 24 \\
\hline & & $>10$ th & 25 & 28 \\
\hline \multirow{2}{*}{6} & \multirow{2}{*}{$\begin{array}{l}\text { Pelatihan } \\
\text { Wifi TB }\end{array}$} & Ya & 13 & 48 \\
\hline & & Tidak & 64 & 4 \\
\hline
\end{tabular}

B. Hasil Analisis Skor Angket Penggunaan Aplikasi Wifi TB

Hasil analisis perhitungan rata-rata skor angket penggunaan aplikasi Wifi TB di wilayah kerja Dinas Kesehatan Kota Semarang disajikan pada gambar 1 .

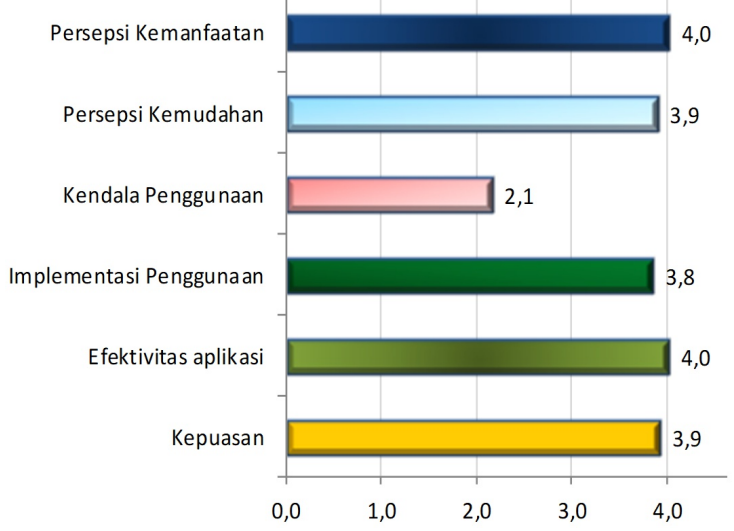

Gambar 1. Average Skor Variabel Penelitian

Dari hasil skor angket diketahui bahwa skor persepsi kemanfaatan \& kemudahan adalah 4 dari 5, artinya responden sadar akan manfaat dan kemudahan aplikasi Wifi TB. Skor kendala penggunaan adalah 2 dari 5, artinya responden tidak begitu mengalami kendala dalam mengoperasikan aplikasi, sehingga tidak menghalangi responden dalam menggunakan aplikasi (terlihat dari skor implementasi penggunaan 3,8).

Skor persepsi efektivitas dan kepuasan adalah 4 dari 5, artinya responden menilai penggunaan aplikasi efektif dan puas terhadap aplikasi wifi TB.

C. Uji Pengaruh Persepsi Kemanfaatan. Kemudahan, \& Kendala terhadap Implementasi Penggunaan Aplikasi

1. Uji Asumsi

1.1 Uji Normalitas

Uji normalitas digunakan untuk menentukan data berdistribusi normal atau tidak. Uji normalitas menggunakan grafik "normality plot", jika data disekitar garis normal artinya data berdistribusi normal. Gambar 2. adalah hasil Normality plot data dari SPSS.

Dependent Variable: Implementasi

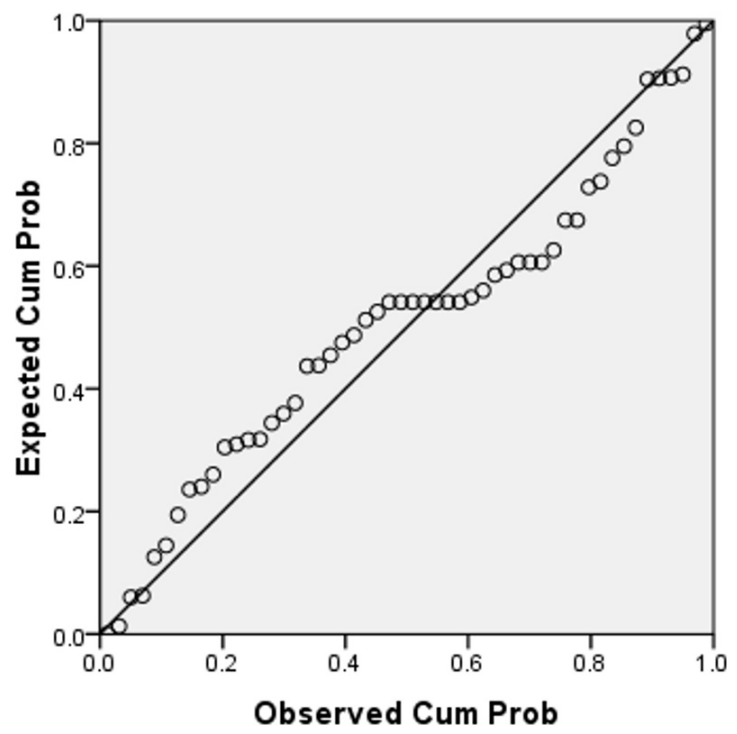

Gambar 2. Normality Plot

Dari Gambar 2, diketahui bahwa data berada disekitar garis normalitas, sehingga data berdistribusi normal.

1.2 Uji Autokorelasi

Uji Autokorelasi dapat diketahui dari nilai Durbin-Watson, jika nilai durbin watson antara dU dan 4-dU artinya tidak ada autokorelasi. Dimana dL dan dU diambil dari durbin watson tabel dengan $\mathrm{K}, \mathrm{N}$. K=jumlah variabel independen, $\mathrm{N}=$ jumlah data responden.

Berdasarkan hasil stastistik diketahui nilai durbin watson $=1,726$ karena of $\mathrm{N}=52$, $\mathrm{K}=3$ the $\mathrm{dU}=1,4339$ dan 4 - $\mathrm{dU}=2,323$, maka $\mathrm{dU}=1,4339<$ Nilai durbin watson $=1,726<$ $4-\mathrm{dU}=2,323$ artinya tidak terjadi 
autokorelasi.

\subsection{Uji Heterokedastisitas}

Uji heterokedastisitas dapat diketahui menggunakan scatter plot, jika data tidak konvergen dan memiliki pola disekitar nilai 0 artinya tidak terjadi heterokedastisitas. Apabila asumsi heteroskedastisitas tidak terpenuhi, maka model regresi dinyatakan tidak valid sebagai alat peramalan. Hasil scatter plot disajikan pada gambar 3 .

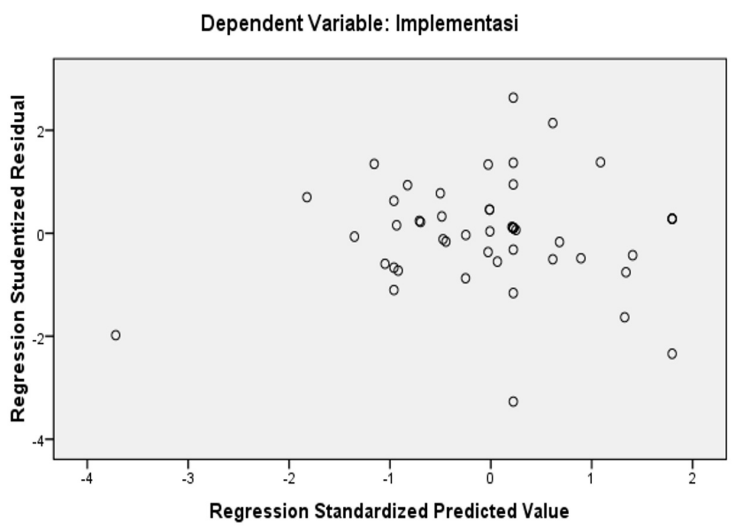

Gambar 3. Scatter Plot

Dari gambar 3 diketahui data konvergen dan tidak membuat pola disekitar nilai 0, maka tidak terjadi heterokedastisitas.

2. Uji Regresi Berganda

Uji regresi berganda dapat diketahui dari hasil sig F, jika nilai sig $F<0,05$ artinya ada pengaruh variabel bebas pada variabel terikat. Dari data diketahui variabel bebas ada 3 yaitu vaiabel persepsi kemanfaatan, kemudahan dan kendala penggunaan aplikasi, sedangkan variabel terikatnya yaitu implementasi penggunaan aplikasi. Nilai sig $F$ hasil output SPSS disajikan pada tabel 2.

Tabel 2. Scatter Plot

\begin{tabular}{|c|c|c|c|c|}
\hline \multirow[b]{2}{*}{ No } & \multicolumn{4}{|c|}{ Koefisien } \\
\hline & Variabel & $\begin{array}{l}\text { Regresi } \\
\text { (B) }\end{array}$ & Thitung & Sig. \\
\hline 1 & Konstanta & 26.602 & & \\
\hline 2 & $\begin{array}{l}\text { Persepsi } \\
\text { kemanfaatan }\end{array}$ & -0.047 & -0.303 & 0.763 \\
\hline 3 & Persepsi kemudahan & 0.838 & 2.343 & 0.023 \\
\hline 4 & Kendala penggunaan & -0.842 & -6.574 & 0.000 \\
\hline \multicolumn{4}{|c|}{$\mathrm{F}$ hitung $=0.000$} & 0.000 \\
\hline \multicolumn{5}{|c|}{ R Square $=0.701$} \\
\hline
\end{tabular}

Dari Tabel 2, diketahui nilai sig $\mathrm{F}=$ $0,000<0,05$ artinya persepsi kemanfaatan, kemudahan dan kendala penggunaan aplikasi secara bersama-sama berpengaruh terhadap implementasi penggunaan aplikasi Wifi TB. Dari hasil analisis diperoleh suatu persamaan untuk prediksi. Persamaan yang diperoleh yaitu sebagai berikut:

$$
\begin{aligned}
& Y=a+b X 1+c X 2+d X 3 \\
& Y=26.602-0.47 X 1+0.838 \times 2-0.842 \times 3
\end{aligned}
$$

Keterangan:

$\mathrm{X} 1$ : persepsi kemanfaatan,

$\mathrm{X} 2$ : persepsi kemudahan

$\mathrm{X} 3$ : kendala pengguanaan

$\mathrm{Y}$ : implementasi penggunaan.

Nilai R square adalah $70,1 \%$ artinya persepsi kemanfaatan, kemudahan dan kendala penggunaan secara bersamasama berpengaruh terhadap penggunaan aplikasi Wifi TB sebesar 70,1\%

D. Hasil Analisis Skor Item Pertanyaan

Hasil analisis skor item pertanyaan disajikan pada Tabel 3 sebagai berikut:

\begin{tabular}{|c|c|c|c|}
\hline No & Item & Pertanyaan & Skor \\
\hline & \multicolumn{3}{|c|}{ Kendala belum menggunakan } \\
\hline 1 & K1 & $\begin{array}{l}\text { Saya tidak mengetahui tentang Wifi } \\
\text { TB pada saat ini }\end{array}$ & 3,2 \\
\hline 2 & K2 & $\begin{array}{l}\text { Aplikasi Wifi TB hanya menambah } \\
\text { beban pekerjaan saya }\end{array}$ & 2,9 \\
\hline 3 & K3 & $\begin{array}{l}\text { Menurut saya aplikasi Wifi TB tidak } \\
\text { memberikan dampak positif bagi } \\
\text { pelayanan }\end{array}$ & 2,9 \\
\hline 4 & K4 & $\begin{array}{l}\text { Saya tidak tahu cara } \\
\text { mengoperasikan aplikasi Wifi TB }\end{array}$ & 3,2 \\
\hline 5 & K5 & $\begin{array}{l}\text { Jenis smartphone tidak memadai } \\
\text { untuk menggunakan aplikasi Wifi }\end{array}$ & 2,8 \\
\hline \multirow[t]{2}{*}{6} & K6 & $\begin{array}{l}\text { Saya belum siap untuk } \\
\text { menggunakan aplikasi Wifi TB }\end{array}$ & 3,0 \\
\hline & \multicolumn{3}{|c|}{ Persepsi Kemanfaatan } \\
\hline 7 & P1 & $\begin{array}{l}\text { Aplikasi mempercepat penyelesaian } \\
\text { tugas dalam melaporkan kasus TB }\end{array}$ & 3,9 \\
\hline 8 & P2 & $\begin{array}{l}\text { Aplikasi memperingan pekerjaan } \\
\text { saya }\end{array}$ & 4,0 \\
\hline 9 & P3 & $\begin{array}{l}\text { Aplikasi membuat hasil pekerjaan } \\
\text { saya lebih terdokumentasi }\end{array}$ & 4,0 \\
\hline 10 & $\mathrm{P} 4$ & $\begin{array}{l}\text { Aplikasi membuat pekerjaan saya } \\
\text { lebih mudah }\end{array}$ & 3,9 \\
\hline 11 & P5 & $\begin{array}{l}\text { Aplikasi dapat diakses oleh bagian } \\
\text { yang membutuhkan }\end{array}$ & 4,1 \\
\hline 12 & P6 & Aplikasi berguna dalam pekerjaan & 4,0 \\
\hline
\end{tabular}

Tabel 3. Analisis Skor Item Pertanyaan 
Tabel 3. Analisis Skor Item Pertanyaan (Lanjutan)

\begin{tabular}{|c|c|c|c|}
\hline No & Item & Pertanyaan & Skor \\
\hline 13 & P7 & Aplikas mempermudah tugas & 3,8 \\
\hline \multirow[t]{2}{*}{14} & P8 & $\begin{array}{l}\text { Aplikasi mudah diakses dari } \\
\text { semua spek smartphone }\end{array}$ & 3,9 \\
\hline & \multicolumn{3}{|c|}{ Kendala Penggunaan } \\
\hline 15 & K1 & $\begin{array}{l}\text { Saya tidak dapat mengoperasikan } \\
\text { aplikasi }\end{array}$ & 2,1 \\
\hline 16 & $\mathrm{~K} 2$ & $\begin{array}{l}\text { Saya tidak mengetahui menu-menu } \\
\text { di aplikasi }\end{array}$ & 2,2 \\
\hline 17 & K3 & $\begin{array}{l}\text { Saya tidak dapat menginput, edit } \\
\text { dan simpan data pasien di aplikasi }\end{array}$ & 2,2 \\
\hline 18 & K4 & $\begin{array}{l}\text { Saya tidak tahu manfaat dan } \\
\text { pentingnya data informasi di } \\
\text { aplikasi }\end{array}$ & 2,1 \\
\hline 19 & K5 & $\begin{array}{l}\text { Saya tidak tahu cara } \\
\text { memanfaatkan informasi kesehatan } \\
\text { untuk membantu pekerjaan }\end{array}$ & 2,2 \\
\hline & \multicolumn{3}{|c|}{ Implementasi Penggunaan } \\
\hline 20 & I1 & $\begin{array}{l}\text { Input data dapat dilakukan dengan } \\
\text { mudah }\end{array}$ & 3,8 \\
\hline 21 & $\mathrm{I} 2$ & Aplikasi mudah digunakan & 3,8 \\
\hline 22 & I3 & $\begin{array}{l}\text { Aplikasi jelas untuk dipelajari dan } \\
\text { dimengerti }\end{array}$ & 3,8 \\
\hline 23 & $\mathrm{I} 4$ & $\begin{array}{l}\text { Tata letak tampilan aplikasi mudah } \\
\text { dikenali }\end{array}$ & 3,8 \\
\hline 24 & I5 & $\begin{array}{l}\text { Spesifikasi smartphone yang ada } \\
\text { mendukung operasional aplikasi }\end{array}$ & 3,8 \\
\hline 25 & I6 & $\begin{array}{l}\text { Koneksi cukup stabil untuk } \\
\text { mengoperasikan aplikasi }\end{array}$ & 3,9 \\
\hline \multicolumn{4}{|c|}{ Efektivitas aplikasi } \\
\hline 26 & IE1 & $\begin{array}{l}\text { Penggunaan membuat saya lebih } \\
\text { cepat melakukan pelaporan kasus } \\
\text { TB }\end{array}$ & 4,0 \\
\hline 27 & IE2 & $\begin{array}{l}\text { Penggunaan aplikasi membuat } \\
\text { saya lebih mudah melakukan } \\
\text { pelaporan kasus TB }\end{array}$ & 4,0 \\
\hline & \multicolumn{3}{|c|}{ Kepuasan } \\
\hline 28 & KEP4 & Saya puas menggunakan aplikasi & 3,8 \\
\hline 29 & KEP5 & $\begin{array}{l}\text { Saya percaya diri dalam } \\
\text { menggunakan aplikasi }\end{array}$ & 3,8 \\
\hline 30 & KEP6 & $\begin{array}{l}\text { Saya merasa mudah melaporkan } \\
\text { data terduga atau kasus TB }\end{array}$ & 4,0 \\
\hline 31 & KEP7 & $\begin{array}{l}\text { Saya puas atas peforma dan } \\
\text { kecepatan aplikasi }\end{array}$ & 3,9 \\
\hline 32 & KEP8 & $\begin{array}{l}\text { Saya percaya aplikasi } \\
\text { meningkatkan kualitas } \\
\text { pemamntauan dan penanganan } \\
\text { kasus TB }\end{array}$ & 4,0 \\
\hline
\end{tabular}

Dari tabel 3 diketahui bahwa pada Kendala belum menggunakan aplikasi disebabkan karena responden tidak mengetahui aplikasi Wifi TB, sedangkan dari segi persepsi kemudahan dan kemanfaatan responden merasa mudah mengakses aplikasi dan aplikasi berguna dalam pekerjaan. Dari segi kendala penggunaan, responden masih kesulitan dalam mengoperasikan aplikasi yaitu dalam menginput, edit dan simpan data pasien di aplikasi. Dari segi implementasi penggunaan, koneksi yang stabil menunjang penggunaan aplikasi, dan dari segi efektivitas-kepuasan responden merasa lebih mudah melaporkan terduga/ kasus TB.

Penelitian yang dilakukan oleh Prasudi dan Utarini tahun 2005 berjudul Model Kemitraan Puskesmas dan Praktisi Swasta dalam Penanggulangan Tuberkulosis Paru di Kecamatan Kalasan Kabupaten Sleman Provinsi DIY, peneliti menyatakan bahwa penerimaan praktisi swasta terhadap notifikasi wajib TB akan sangat bergantung kepada pendekatan yang dilakukan oleh Dinas Kesehatan dan Puskesmas sebagai aktor-aktor kunci dimana kapasitas internalnya juga harus diperkuat (Prasudi dan Utarini, 2005).

Pendekatan awal yang tepat, pengenalan sikap afektif dan komunikasi berkelanjutan akan memperingan beban dan mengatasi masalah etnisitas tentang notifikasi wajib TB. Selain itu pemahaman awal yang baik ditambah pemahaman lanjut yang komprehensif dan penguatan kapasitas menjadi modal penting bagi koherensi intervensi dalam acceptability notifikasi wajib TB pada praktisi swasta (Kurniawati et al., 2019).

Menurut penelitian Uplekar et al. (2016) yang dikutip dalam penelitian Ari Kurniawati et al. (2019) menyatakan bahwa komponen yang diperlukan dalam pelaksanaan notifikasi wajib kasus TB yaitu kebijakan dan peraturan, sistem dan mekanisme pelaporan, orientasi dari penyedia layanan kesehatan, pengawasan dan evaluasi, dan umpan balik (Kurniawati et al., 2019).

Selain itu penelitian yang dilakukan oleh Yanogo et al., 2015 pada Department 
Somme Prancis menemukan bahwa waktu untuk notifikasi wajib kasus TB lebih lama dari yang direkomendasikan sehingga dibutuhkan kolaborasi yang lebih baik antara pihak yang terlibat dalam pengendalian TB dan pendidikan medis yang berkelanjutan untuk mengurangi waktu keterlambatan tersebut (Yanogo et al., 2015).

\section{KESIMPULAN DAN SARAN}

Dari hasil penelitian dapat ditarik kesimpulan bahwa persepsi kemanfaatan, kemudahan dan kendala penggunaan secara bersama-sama berpengaruh signifikan terhadap penggunaan aplikasi Wifi TB sebesar 70,1\% di wilayah kerja Dinas Kesehatan Kota Semarang.

Responden yang berpengalaman kerja lebih sadar akan penggunaan aplikasi Wifi TB dalam melaporkan kasus TB. Persentase responden yang tidak mengikuti pelatihan aplikasi Wifi TB sebesar $83 \%$. Dari hasil analisis rata-rata skor penggunaan aplikasi Wifi TB, diketahui bahwa responden sadar akan manfaat dan kemudahan aplikasi Wifi TB, responden tidak begitu mengalami kendala dalam mengoperasikan aplikasi, sehingga tidak menghalangi responden dalam menggunakan aplikasi Wifi TB dan aplikasi efektif dalam melaporkan kasus TB dan puas terhadap aplikasi Wifi TB.

Oleh karena itu, disarankan kepada pengembang program dan dinas terkait untuk selalu memberikan sosialisasi dan pelatihan kepada pengguna aplikasi Wifi TB, sosialisasi juga dapat dilakukan melalui media sosial.

\section{DAFTAR PUSTAKA}

Badan Pusat Statistik Provinsi Jawa Tengah. (2017). Jumlah Kasus HIV/ AIDS, IMS, DBD, Diare, TB, dan Malaria Menurut Kabupaten/Kota di Provinsi Jawa Tengah. Jateng.Bps.Go.Id. https:// jateng.bps.go.id/dynamictable/ 2019/02/19/400/jumlah-kasus-hiv- aids-ims-dbd-diare-tb-dan-malariamenurut-kabupaten-kota-di-provinsijawa-tengah-2017-2018.html

Indah, M. (2018). InfoDATIN Pusat Data Dan Informasi Kementerian Kesehatan RI. Kementerian Kesehatan RI, Pusat Data dan Informasi. https:// pusdatin.kemkes.go.id/resources/ download/pusdatin/infodatin/ infodatin-tuberkulosis-2018.pdf

Kemenkes RI. (2011). Pedoman Nasional Pengendalian Tuberkulosis (A. Surya, C. Basri, \& S. Kamso (eds.); Edisi 2). Direktorat Jenderal Pengendalian Penyakit dan Penyehatan Lingkungan Kementerian Kesehatan RI.

Kemenkes RI. (2015). Rencana Strategis Kementerian Kesehatan Tahun 20152019.

Kementerian Kesehatan RI. (2018). Profil Kesehatan Indonesia Tahun 2017. Kementerian Kesehatan RI.

Kurniawati, A., Mahendradhata, Y., \& Padmawati, R. S. (2019). Acceptability Notifikasi Wajib Tuberkulosis (TB) pada Dokter Praktik Mandiri dan Klinik Pratama Swasta di Kota Yogyakarta. Jurnal Kebijakan Kesehatan Indonesia: JKKI, 8(1), 1-9. https:// doi.org/10.22146/JKKI.37426

Prasudi, A., \& Utarini, A. (2005). Model Kemitraan Puskesmas-Praktisi Swasta Dalam Penanggulangan Tuberkulosis Paru di Kecamatan Kalasan, Kabupaten Sleman, Provinsi DIY. Jurnal Manajemen Pelayanan Kesehatan, 08(03), 131-139. https:// jurnal.ugm.ac.id/jmpk/article/view/ 2928

World Health Organization. (2018). Global Tuberculosis Report 2018. https:// apps.who.int/iris/bitstream/handle/ 10665/274453/9789241565646-eng.pdf

Yanogo, P. K., Schmit, J. L., Fresse, A. S., Andrejak, C., Castelain, S., Adjodah, C., \& Ganry, O. (2015). Factors associated with time to mandatory tuberculosis notification in the Somme department, France. Revue 
Implementasi Aplikasi Wifi TB Berdasarkan Persepsi Kemudahan...

d'Epidemiologie et de Sante Publique, 63(5), 299-303. https://doi.org/10.1016/ j.respe.2015.06.006 